\title{
IV. Observations on the economical use of the Ranunculus aquatilis; with introductory remarks on the acrimonious and poisonous quality of some of the English species of that genus
}

Richard Pulteney M.D. F.R.S. L.S.

To cite this article: Richard Pulteney M.D. F.R.S. L.S. (1800) IV. Observations on the economical use of the Ranunculus aquatilis; with introductory remarks on the acrimonious and poisonous quality of some of the English species of that genus, Philosophical Magazine Series 1, 6:23, 210-215, DOI: $10.1080 / 14786440008677214$

To link to this article: http://dx.doi.org/10.1080/14786440008677214

曲 Published online: 18 May 2009.

Submit your article to this journal ¿

Џll Article views: 2

Q View related articles ¿ 


\section{[ 210$]$}

IV. Obfervations on the Economical Ufe of the Ranunculus aquatilis; with Introductory Remarks on the acrimonious and poifonous Quality of fome of the Englijh Spyecies of that Genus. By Richard Pulteney, M.D.F.R.S. and L.S. *

B Materia Medica agree, pretty uniformly, in attributing to many fpecies of the genus Ranunculus a corrofive and poifonous quality. In feveral it abounds in fuch a degree as, when applied externally, in a recent ftate, to excite vefications, and ulceration of the parts, frequently of a malignant and gangrenous nature; and, when taken inwardly, to prove poifonous and fatal, by inducing vomiting, inflammation of the ftomach, with the ufual confequences of acrid poifons. Thefe qualities are particularly manifeft in the recent plant, while in its higheft vigour before flowering; and more intenfely in the germen of the flower itfelf, and in the petals of fome.

The poifonous fpecies, that are indigenous, and common in England, are, the Ranunculus Flammula, or Leffer Spearwort ; R. bulbofus, bulbous-rooted Crowfoot; R. acris, upright Crowfoot; R. Jceleratzs, Marh Crowfoot; R. arvenjis, Corn Crowfoot; and the $R$. aquatilis, or Water Crowfoot, according to the report of various authors. Of thefe the Flammula, bulbofus, and feeleratus, are judged to be the moft acrimonious.

Before the introduction of Cantharides, the acrid Rantunculi were, all in their turn, ufed as veficatories; and Haller tells us $t$, the $R$. Flammula is ftill in ufe as fuch in fome parts of France.' Gilibert affures us $\ddagger$ that the $R$. bulbofus veficates with lefs pain than the fies, and has no effect on the urinary

* From the Tranfactions of tbe Limnatan Sacicty, Vol. V.

+ See the Entmeratio Stirpium and Hiforia Stirpium Helvetice, in which much fatisfactory information is collected refpecting the properties. of this genus of plants; and for which the author has, with his ufual candour and accuracy, quoted all his authorities.

+ Plante rariores Lithuanice, No. 331 . 
paffages. He gives it therefore a decided preference as an epifpaftic. Other authors allow thefe qualities in the $R a-$ nunvuli, and that they are quicker than Cantbarides in their veficating effect; but fay, that all thefe advantages are more than balanced by the greater uncertainty of their action on the fkin, and their frequently leaving ill-conditioned ulcers, of which Murray and other writers have recorded infances.*. Neverthelels, the Ranunculi were employed in local fpafmodic complaints and in fixed pains, and not unfrequently in cataplafms to the wrifts in intermitting fevers. Crowfoot is known alfo to have been one of the ingredients in Plunket's epithem for cancers.

The acrimony of thefe plants is, however, of fo volatile a nature, that, even in the moft virulent, it is wholly diffipated in drying; fo that, in the form of hay, they appear to be harmlefs, and nutritive to cattle. It is alfo inftantly expelled in decoction, probably in all the fpecies; at leaft, Murray in forms us, that the Thepherds of Morlachia eat even the $R$. fceleratus, as a culinary plant, after boiling it: the $R$. aurico. $m u s$, and, as feveral authors affure us, the $R$. repens, are fo deftitute of acrimony as to be wholly inoffenfive, and even worthy of a place amóng oleraceous plants.

The Ranunculi give out this quality wholly in diftillation: the water of the $R$. feeleratus, by the experiments of Tilebein, as recorded in the fecond volume of the Cbemical Annals, is acrimonious in an intenfe degree, and, when cold, depofits cryftals which are fcarcely foluble in any mentruum, and are of an inflammable nature $t$. The diftilled water of the R. Flammula, or Leffer Spearwort, as we are informed by $\mathrm{Dr}$. Withering, is an enetic more inftantaneous, and lefs offenfive during its action, than white vitriol; and, as if $\mathrm{Na}$ ture had furnithed an antidote to poifon from among poifons of its own tribe, is to be preferred in promoting the inftant expulfion of deleterious fubftances from the fomach.

In the experiments of the Pan Suecus, even in the improved edition by Schreber, after the obfervations and renewed trials of Kalm, Gadel, Bergius, and Laftbohm, made upon horned cattie, goats, theep, horfes, and fwine, all the

* Asparat. Medicam. iii. 87.

+ Page 313 .

E e 2 
fpecies of Ranunculi, with which trials were made, except the $R$. auricomus, were rejected by the horned cattle; and it is well known, that while our meadows and paftures are eaten bare of other vegetables, the $R$. acris and $R$. bulbojus, which are but too plentiful, are left untouched: neither do cattle willingly eat the $R$. repens, although it is not wholly rejected by horfes, theep, and goats.

The R. Flammula, according to the above experiments, was eaten only by horfes, to which animal it is there faid to be very grateful; whereas the $R$. auriconus, eaten by all the reft, (except that fwine choofe only the roots,) was rejected by horfes. The R. feleratus, which is fuppofed to be the Herba Sardonia of Diofcorides, was touched by goats alone; the $R$. bulbofus only by the latter, though it is well known in England that bogs are fond of the roots. The $R$. acris was eaten by theep and goats; but the $R$. aquatilis is recorled as the only one rejected by all the five fpecies of animals on which thefe trials were made. It does not appear by either edition of the Pan Suecus, that any trials were made with $R$. arvenfis; and though horned cattle and horfes will eat this fpecies greedily, (although not without fubfequent injury,) yet it is known to have been highly deleterious to theep. A notable inftance of this occurred in Piedmont in the year 1786 , where a number of thefe animals died, as it was at firft fuppofed, of an epidemical difeafe; but fubfequent examination difcovered that this deftuction was owing to the Ranunculus arvenfis. The hiftory of this accident is circumftantially related in the Memoirs of the Rnyal Academy of Turin, by M. Brugnon *. The herb grows luxuriantly in Picdmont, and the fheep fed with much eagernefs upon it. The effects here mentioned were not immcdiate, but progreflive; and M. Brugnon, on further inveftigation, was convinced thcy were principally owing to the ronts of the plant; fince, by experiments purpofely made on dogs, thefe animals were almoft inftantly killed by them. On the diffection of the fheep, all the four concoctive organs were found affected with eryfipelatous and gangrenous fpots;

* Memoires de l'Acadímie Royale des Sciences, ¿̇nuées 1788-1789, à Turin. 4to, 1790 . 
but more particularly the abomafum, which he found much more deeply ulcerated than the others; and the mifchief had extended into the fmaller inteftines.

The avidity with which theep, horfes, and cows, eat the Ranunculus arven/ss, is, as M. Brugnon juftly obferves, an exception to the commonly received maxim, that herbivorous animals are, by inftinct, led to reject whatever is nuxious. We fee frequently that hunger will impel our domefticated cattle, efpecially on being firft turned to grafs in the fpring, to eat almolt all vegetables promifcuouly. Some of our farmers are aware of the effects of Crowfoot, of which the $R$. acris and $R$. bulbofus are fo common in our paftures, and by which the mouths of their cattle are frequently inflamed and bliftered; and doubtlefs the effects often extend much further, and fometimes prove fatal. There can be little doubt of the fame deftructive confequences from other poifonous plants, in cafes where the caufe is little fufpected.

M, Krapf, who inftituted a fet of experiments wholly confined to this genus of plants ${ }^{*}$, attributes to the $R$. aquatilis the deleterious qualities belonging to the others; obferving, that it will veficate the fkin, but is flower in its operation than the $R$. bulbofus and $R$. focleratus. Bithop Gunnerus alfo, in his Flora Norvegiat, tells us, that this fpecies is not lefs noxious to cattle than the $R$. fceleratus; that even the goat, an animal lefs nice in the felection of its food than the others, leaves it wholly untouched.

It is well known to botanifts, that the Ranunculus aquatilis of Linnæus comprehends four fpecies of the older writers; and even Haller, and fome more modern authors, ftill keep them feparate: among whom, the late profeffor Sibthorp, in his Flora Oxonienfis, enumerates them diftinetly, under the names of, r. R. beteroplyllus, or R. aquatilis .Ger. em. 829 . Ray Syn. 249. 2. R. aquatilis, or R. aquatilis omnino tenuifolius $J . B$. iii. 78I. Ray Syn. 249. 3. R. circinatus, R. aquaticus albus, circinatis tenuiffime divifis folie, floribus ex alis longis pediculis innixis Pluk. alm. 3 II. t. 55.2. Ray

* C. Krapf, Experimenta de nonnullorum Ranunculorum venenatâ qualitate, horum externo et interno ufu. Viennes 3766.8 vo. p. 107.

+ No. 646 . 


\section{Economical Ufe of the Ranunculus aquatilis.}

Syn. 249. and 4. R. furviatilis, or Ranunculo five Polyanthemo aquatili albo affine, Millefolium maratriphyllum fluitans. J. B. iii. 782. Without entering here into any difquifition relative to thefe diftinctions of the fpecies, I thall come to the ultimate object of thefe obfervations, by remarking, that I was lately witnefs to a fact, with refpect to the Ranunculus aquatilis fluviailis, which, after what $I$ recollected of the character of the plant, fomewhat furprifed me, while it fufficiently proved, not merely the innoxious quality of this plant, but that it is nutritive to cattle, and capable of being converted to ufeful purpofes in agricultural economy. Unlefs thefe varieties of the $R$. aquatilis Limn. be endowed with different properties, it is a proof that the experiments on this plant were not marle with fufficient accuracy, or difcrimination of the varieties; not fufficiently repeated on different individuals of the fame fpecies of animals; or, that in different countries or fituations it is divefted of its virulence. In the prefent inftance, it is probable, the plant is rendered inert as a poifon, by growing in the water; although in certain other inftances, moifture is thought to heighten the deleterious property of vegetables, efpecially in the umbelliferous tribe.

The fact that I bave alluded to is, that in the neighbourhood of Ringwood, on the borders of the Avon, which affords this vegetable in great abundance all the year, fome of the cottagers fuftain their cows, and even horfes, almoft wholly by this plant; fince the remaining part of their food is nothing more than a fcanty pittance they get on the adjacent heath, which affords little more than Ling, Licben, Bogmofs or Spbagnum, \&c. It is ufual to employ a man to collect a quantity for the day every morning, and bring it in the boat to the edge of the water, from which the cows, in the inftance I faw, ftood eating it with great avidity. I was indeed informed they relifhed it fo highly, that it was unfafe to allow them more than a certain quantity; $J$ think between twenty-five and thirty pounds each, daily; but with variation according to circumftances. The cows I faw were apparently not in a mean condition, and gave a fufficient quantity of good milk. I was told by the perfon whofe cattle 
were feeding on it, that he kept five cows and one horfe fo entirely by this plant, and what the heath afforded, that they had not confumed more than half a ton of hay throughout the whole year; none being ufed, except when the river is frozen over. I examined the whole parcel, on which four cows were feeding, in the beginning of March, and found the whole confifted, exclufively, of the Ranunculus fluviatilis, without any mixture of the Potamogeton, Carex, Sparganium, or other aquatic plants. In fummer, however, it can fearcely be avoided but that there muft be a mixture of fome of thefe : but other plants are not chofen.

This account was confirmed to me by different perfons; by whom I was further informed, that hogs are alfo fed with the fame plant, on which they improve fo well, that it is not neceffary to allow them other fuftenance till it is proper to put them up to fatten.

This relation, while it fhows how carefully experiments fhould be conducted before a decifive judgment on the powers of any reputedly poifonous vegetable can be formed, may in:duce fuch as were unacquainted with this fact to adopt the ufe of this plant in fimilar fituations, fince it is one of the moft frequent in many rivers of this kingdom. The application of it to thefe ufeful purpofes will alfo anfwer a fecondary good-of tending to clear the ftreams of what is otherwife confidered as a noxious weed; fince, by its abundance in fummer, it is frequently feen to choke up the rivers more than any other plant, and, from night falls of rain, contributes much to the overflowing of meadows in hay-time.

V. Defcription of the Mus Burfarius, from a Drawing communicated by Major-General Thomas Davies, F.R.S. \& L.S. By George Shaw, M.D.F.R.S.V.P.L.S.*

$\mathrm{T}$

HE Mus burfarius belongs to a particular divifion in the genus, containing fuch fpecies as are furnifhed with cheek-pouches for the temporary reception of their food. It feems not to have been yet defcribed, or at leaft not fo.

* From the Tranfadtions of the Lininean Society, Vol. V. 